\title{
Molecular Mechanisms of Chitosan Interactions with Fungi and Plants
}

\author{
Federico Lopez-Moya *(D), Marta Suarez-Fernandez ${ }^{\mathbb{D}}$ and Luis Vicente Lopez-Llorca
}

Department of Marine Sciences and Applied Biology, Laboratory of Plant Pathology, Multidisciplinary Institute for Environmental Studies (MIES) Ramon Margalef, University of Alicante, 03080 Alicante, Spain; suarezfernandezmarta@gmail.com (M.S.-F.); lv.lopez@ua.es (L.V.L.-L.)

* Correspondence: federico.lopez@ua.es; Tel.: +34-9-6590-3400 (ext. 2223)

Received: 6 November 2018; Accepted: 11 January 2019; Published: 15 January 2019

\begin{abstract}
Chitosan is a versatile compound with multiple biotechnological applications. This polymer inhibits clinically important human fungal pathogens under the same carbon and nitrogen status as in blood. Chitosan permeabilises their high-fluidity plasma membrane and increases production of intracellular oxygen species (ROS). Conversely, chitosan is compatible with mammalian cell lines as well as with biocontrol fungi (BCF). BCF resistant to chitosan have low-fluidity membranes and high glucan/chitin ratios in their cell walls. Recent studies illustrate molecular and physiological basis of chitosan-root interactions. Chitosan induces auxin accumulation in Arabidopsis roots. This polymer causes overexpression of tryptophan-dependent auxin biosynthesis pathway. It also blocks auxin translocation in roots. Chitosan is a plant defense modulator. Endophytes and fungal pathogens evade plant immunity converting chitin into chitosan. LysM effectors shield chitin and protect fungal cell walls from plant chitinases. These enzymes together with fungal chitin deacetylases, chitosanases and effectors play determinant roles during fungal colonization of plants. This review describes chitosan mode of action (cell and gene targets) in fungi and plants. This knowledge will help to develop chitosan for agrobiotechnological and medical applications.
\end{abstract}

Keywords: chitosan; antimicrobial compounds; auxin; effectors; LysM motifs; plant immunity; ROS

\section{Introduction}

Chitosan is a linear polymer of beta-(1-4)-linked $\mathrm{N}$-acetyl-2-amino-2-deoxy-D-glucose (acetylated) and 2-amino-2-deoxy-D-glucose (deacetylated [1]) subunits (Figure 1) [2]. Partial deacetylation of chitin by enzymatic or chemical processes generates chitosan [3]. Chitin is a key component of the cuticle of insects and exoskeleton of crustaceans, the cell wall of true fungi and that of some algae [1]. The main sources of chitosan production for commercial applications are marine crustaceans (mainly shrimps). The main way to synthetize chitosan is by chemical methods. Acids demineralize crustacean exoskeletons. Sodium hydroxide removes proteins from demineralized shells. Strong bases deacetylase chitin and yield chitosan [4]. Enzymatic methods can also produce chitosan. Chitin deacetylases (CDAs) generate chitosan from chitin. Combinations of chitin oligosaccharide deacetylases modify the pattern of polymer deacetylation [5-7]. Some fungal plant pathogens generate chitosan [8] during early infection to avoid host defenses [9]. CDA from the endophyte Pestalotiopsis sp. generates chitosan oligomers that unlike its chitin substrates no longer elicit plant immunity [10]. The nematophagous fungus Pochonia chlamydosporia produces chitosan during Meloidogyne javanica egg infection [11]. The fungus overexpresses CDA and chitosanase encoding genes in this process [11]. The activity of the catalytic center of a CDA encoded in the P. chlamydosporia genome has been recently confirmed experimentally [12]. 


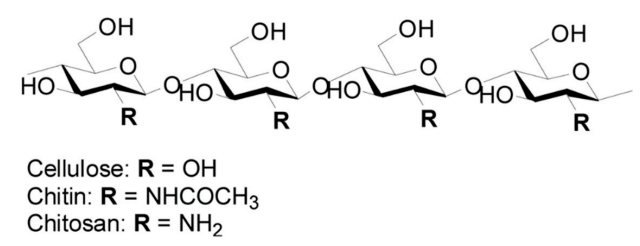

Figure 1. Chitosan, chitin and cellulose molecular structures (Modified from [2]).

Degree of deacetylation and molecular weight are crucial parameters for chitosan bioactivity. Chitosans usually have a degree of acetylation of less than $10 \%$ [3]. Numbers of $\mathrm{N}$-acetyl glucosamine and glucosamine subunits in the molecule define chitosan molecular weight (Mw) [3]. Large-Mid (70-100 kDa) Mw chitosans are soluble in weak acid solutions (e.g., hydrochloric acid, citric acid, acetic acid). Only chitosan oligosaccharides ( $<5000 \mathrm{Da}$ ) are water-soluble. Protonation of chitosan amino groups generates positive charges. Both positive charge and amenability to structural modifications confer chitosan numerous biological properties. Wide varieties of industries use chitosan for different applications. Chitosan has potential for drug-delivery $[3,13,14]$ or as a source of biomaterials to generate nanofibers or nanoparticles [15-17]. This review describes the mode of action of chitosan in fungi and plants. Figure 2 shows the main features summarized in this paper. Our main objectives are: (1) Analyze antimicrobial activity of chitosan; (2) Describe cell and gene targets for chitosan in fungi; (3) Illustrate agrobiotechnological applications of chitosan; (4) Discuss the effect of chitosan on plant growth and immunity.

\section{Chitosan}

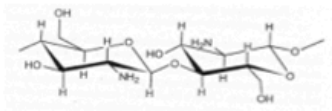

Affects fungal growth and differentiation
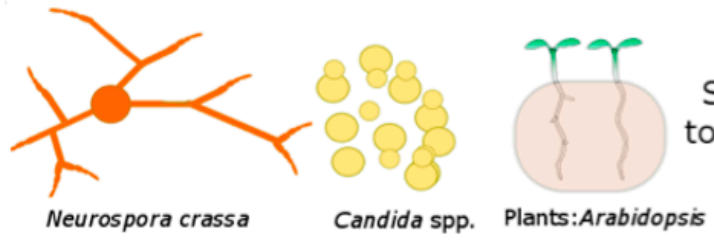

Sensitive

to chitosan

(S)
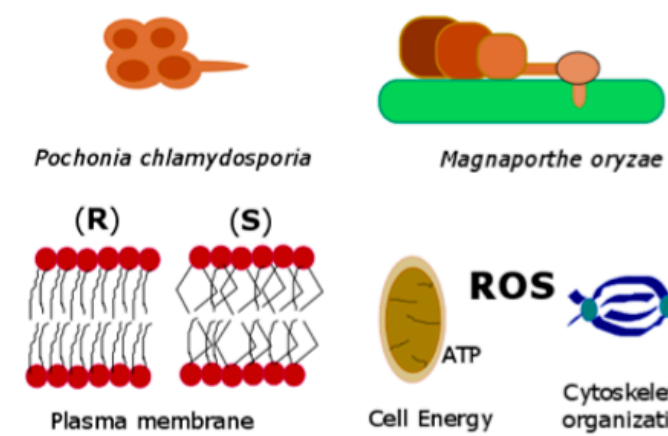

Resistant

to chitosan

(R)
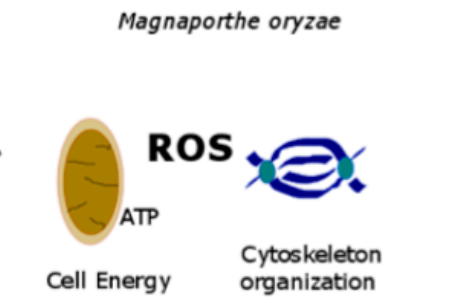

(R)

(S)

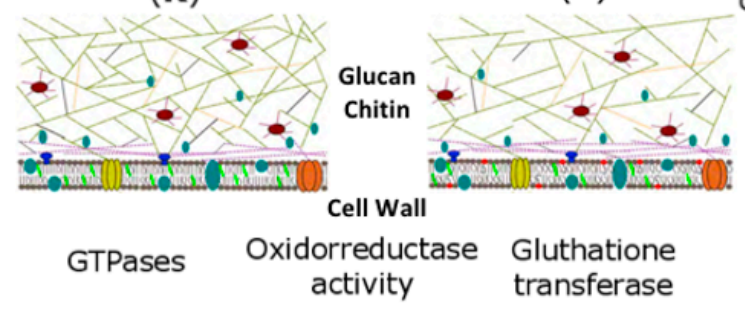

Chitosan

cell/gene

targets

Figure 2. Conceptual diagram of chitosan as antifungal and gene modulator in fungi and plants (modified from [18]). 


\section{Chitosan as Antimicrobial Agent}

Chitosan is a versatile compound with antimicrobial activity [18-21]. Several studies have investigated the mode of action of chitosan [22-24]. In this review, we present an overview on the state-of-the-art of chitosan as a natural fungicide. Chitosan affects germination and hyphal morphology of economically important post-harvest fungal pathogens (e.g., Rhizopus stolonifer and Botrytis cinerea) [25-28]. This polymer also inhibits the growth of many other plant pathogenic and mycoparasitic fungi (such as Alternaria spp., Colletotrichium spp. or Trichoderma spp.) [20,29-31].

Chitosan has a great potential as antifungal agent to treat diseases caused by human pathogenic fungi [32-36]. Sensitive fungi show energy-dependent plasma membrane permeabilisation by chitosan [37]. This polymer also displays antibiotic activity against pathogenic bacteria [23,38-41]. Just as for fungi, chitosan permeabilises bacterial plasma membranes [36]. Recent studies suggest the use of chitosan as antimicrobial for clinical use [42]. This polymer kills opportunistic human pathogens such as Fusarium proliferatum and Hamigera avellanea [43]. Chitosan also arrests germination and growth of Fusarium oxysporum f.sp. radicis lycopersici and Verticillium dahliae [29]. These fungi are phylogenetically close to opportunistic human pathogens. This polymer also restricts growth of other fungal human pathogens such as Aspergillus fumigatus and Rhizopus stolonifer. Chitosan inhibits biofilm formation in A. fumigatus [44]. Limitation of nutrients (carbon; C and nitrogen; N) enhances chitosan antifungal activity to human pathogens [43]. Deprivation of nutrients modifies cell wall architecture which affects fungal growth [43,45-47]. To this respect, low branching (glucan content) of fungal cell wall increases sensitivity to chitosan (Figure 2) [11]. There is a direct link between cell wall and membrane since the synthesis of key cell wall components (glucans and chitin) is performed by plasma membrane-associated synthase complexes [48,49]. Chitosan inhibits growth of Candida spp. and Cryptococcus spp. pathogenic yeasts [34,36,42,50-52]. As for filamentous fungi, chitosan inhibits C. albicans growth under the same nutritional status (carbon) as in human blood (glycemia). Chitosan significantly reduces C. albicans virulence on Galleria mellonella L. under these conditions [36]. G. mellonella is a well-established model host to test the effect of antimicrobials on virulence of fungal and bacterial pathogens [53-55]. This polymer is harmless to mammalian (human and monkey) cells at concentrations fungicidal to human fungal pathogens [43]. This makes it suitable for clinical application. Nanotechnology allows new chitosan formulations (e.g., nanofibres, nanocomposites, or nanocapsules) with potential for drug delivery, in medical mycology and biotechnology [24,56-61]. These findings open-up new possibilities to develop chitosan as a natural antifungal compound for practical use.

\section{Chitosan Alters Gene Expression in Fungi}

Several studies have investigated the role of plasma membrane in the sensitivity of fungi to chitosan [37,62]. The membranes of chitosan-sensitive fungi (e.g., Neurospora crassa) are highly-fluid (rich in polyunsaturated free fatty acid (FFA) such as linolenic acid). On the contrary, chitosan-resistant fungi (P. chlamydosporia) have low-fluidity membranes (enriched on saturated FFA such as palmitic or stearic acid [62]). Recently, our group found that chitosan permeabilises N. crassa plasma membrane using flow cytometry. This triggers intracellular production of reactive oxygen species (ROS) and cell death [43]. RNAseq data and gene ontology (GO) analysis reveals oxidoreductase activity, plasma membrane and transport as main categories induced by chitosan [36]. Chitosan also enriches oxidative metabolism, respiration and transport GO functions in the model yeast Saccharomyces cerevisiae [63]. S. cerevisiae plasma membrane, response to stress and cell wall integrity genes are induced by chitosan [64]. Testing deletion strain mutants confirms Lipase Class III, Monosaccharide transporter and Glutathione transferase encoding genes (NCU03639; NCU04537; NCU10521, respectively) as main chitosan targets in N. crassa [36]. They might play a role in membrane repair, assimilation of catabolites and buffering ROS surplus derived from chitosan damage. Antifungal proteins, such as PAF from Penicillium chrysogenum, have a mode of action similar to chitosan since they also permeabilise plasma membranes and induce ROS production $[65,66]$. Synthesis of oxidative by-products of metabolism 
reflects (in peroxisomes and mitochondria) the energetic status of the cell. This would explain why plasma membrane permeabilisation by chitosan is an energy dependent process [37]. A chemical or physiological block of the electron transport chain abolishes the antifungal activity of chitosan in N. crassa [37]. Peroxisome and mainly mitochondria, the main organelles involved in ROS generation, support the relevance of ROS metabolism in the response of N. crassa to chitosan. The early response of N. crassa to chitosan involves partial membrane permeabilisation and the onset of ROS production [43]. We hypothesize that chitosan causes an intracellular ROS burst which starts oxidizing FFA from cell membranes. Increased membrane oxidation finally leads to full plasma membrane permeabilisation and is perhaps responsible for the antifungal effect of chitosan. Induction of ROS and growth inhibition also happen under glucose starvation in Candida glabrata $[67,68]$. This again links nutrient content, ROS and antifungal action and may explain results described above with chitosan. Future studies should investigate the generation of oxylipins, metabolites derived from lipid peroxidation, [69] by chitosan and its relationship with the cellular nutritional status. Recent works describe the involvement of $\mathrm{Ca}^{2+}$ on plasma membrane remodeling during cell fusion in N. crassa $[70,71]$ and S. cerevisiae [72]. This would explain why $\mathrm{Ca}^{2+}$ increases tolerance to chitosan in N. crassa [36]. On the contrary, N. crassa syt1 deletion strains involved in plasma membrane homeostasis mediated by $\mathrm{Ca}^{2+}[73,74]$ are more sensitive to chitosan than the wild-type strain [36]. Figure 3 shows a model we propose on the mode of action of chitosan on sensitive fungi. The link of ROS, membrane homeostasis, $\mathrm{Ca}^{2+}$ and chitosan is therefore an attractive subject for future studies [75-77]. 


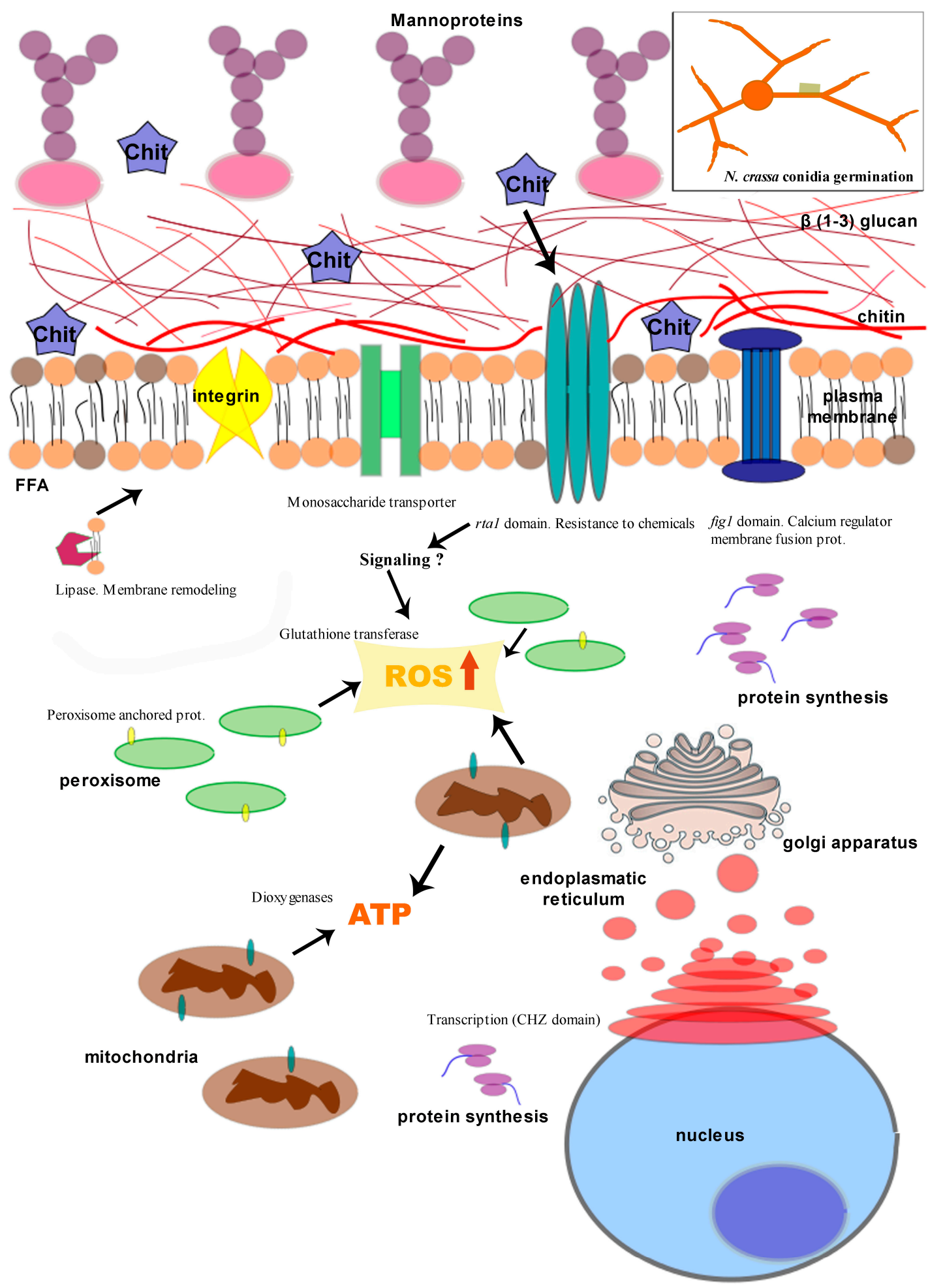

Figure 3. Proposed mode of action of chitosan as a gene modulator on sensitive fungi. A lipase modifies the plasma membrane increasing its permeability and $\mathrm{Ca}^{2+}$ would mediate this in association with a calcium regulator membrane fusion protein with a FIG1 domain. Moreover, a monosaccharide transporter could be involved in the assimilation or detoxification of monomers of $N$-acetyl glucosamine. Besides, a glutathione transferase and two dioxygenases may be associated with the response of the fungus to oxidative stress caused by chitosan increasing reactive oxygen species (ROS) and ATP production. Finally, the mechanisms of protein synthesis (peroxisome-anchored protein) and resistance to chemicals (RTA1 domain) have also modifications in their gene expression when exposed to chitosan (modified from [36]). 


\section{Chitosan Acts as Gene Modulator in Tolerant Fungi}

Chitosan can be combined with tolerant fungi such as biocontrol fungi (BCF) $[29,57,78,79]$. BCF can degrade chitosan using it as a nutrient source $[29,80]$. Nematophagous fungi such as P. chlamydosporia can withstand high doses of chitosan. The genome of P. chlamydosporia [81] reveals an expansion of hydrolases. This may reflect the multitrophic (saprotrophic, endophytic, nematophagous) behavior of the fungus. P. chlamydosporia encodes enzymes to generate and degrade chitosan such as chitin deacetylases or chitosanases [81]. Recent studies show that chitosan induces these genes in P. chlamydosporia (mainly $c d a 1, \operatorname{csn} 1$ and $\operatorname{csn} 6$ ) during nematode egg infection [12]. Other studies demonstrate that chitosan also induces P. chlamydosporia proteases [79]. Proteomics reveals that chitosan alone induces expression of $v c p 1$ serine protease also involved in nematode egg infection by $P$. chlamydosporia [82]. Chitosan also induces accumulation of $v c p 1$ and $s c p 1$ (a serine carboxypeptidase) proteases in appressoria of $P$. chlamydosporia infecting root-knot nematode eggs, enhancing virulence [79]. Chitosan also increases sporulation of BCF (P. chlamydosporia and Beauveria bassiana; [29]). Other studies reveal that chitosan enhances growth and sporulation in mycoparasitic biocontrol fungi Trichoderma spp. (such as T. koningiopsis) [31]. However, other Trichoderma spp. are hypersensitive to chitosan such as T. harzianun or T. neocrassum $[29,31]$. Tolerance of fungi to chitosan depends on the FFA composition as we have explained above. T. knoningiopsis, resistant to chitosan shows plasma membrane enriched in saturated FFA. Contrarily, other Trichoderma spp. highly sensitive to chitosan display a large content of poly-unsaturated FFAs [31]. The use of chitosan in combination with BCF opens new environmentally friendly possibilities to manage pest and diseases caused by insects, nematodes or fungi.

\section{Agrobiotechnological Applications of Chitosan}

\subsection{Chitosan in Plant Protection}

Abuse of pesticides and fertilizers generates environmental pollution, eutrophication and loss of biodiversity [83-85]. Chitosan is widely used in agriculture on pre- and postharvest treatments of crops to control microbial infections $[56,86,87]$. Chitosan can solve these problems minimizing pollution. For example, nanoparticles of chitosan and porous silica can encapsulate pesticides and fertilizers and reduce their environmental impact [88]. Application of chitosan to plants protects them against infections caused by important plant pathogenic fungi such as B. cinerea or F. oxysporum f.sp. radicis-lycopersici [89-91]. Chitosan promotes parasitism of root-knot nematode eggs by P. chlamydosporia [79]. In combination with Hirsutella, chitosan can control cyst nematodes in soybean [92]. In recent studies, chitosan enhances pathogenicity of $P$. chlamydosporia to root-knot nematode (RKN) eggs in greenhouse and semi-field experiments [93]. This opens up new strategies for sustainable management of plant-parasitic nematodes in economically important crops such as tomato, barley or soybean.

\subsection{Chitosan in Crop Growth and Defenses}

This polymer also stimulates seed germination and growth of seedlings of ornamental plants [94,95]. Chitosan is also an elicitor of plant defenses in economically important crops [96,97]. Effects of chitosan on plant development and immunity are revised below.

\section{Chitosan Effect on Plant Development}

Most chitosan treatments to plants have been performed on leaves. High doses of chitosan in the rhizosphere of Arabidopsis, tomato or barley significantly arrest root development [98]. Chitosan alters root cell morphology and pattern of division. This abolishes polarity of root apex growth, stops elongation and modifies root architecture. Arabidopsis thaliana is an adequate tool to analyze the mechanisms of root growth inhibition by chitosan. Chitosan causes accumulation of auxin (mainly indole acetic acid; IAA) in Arabidopsis roots. This accumulation is mediated by induction of 
Tryptophan-dependent biosynthesis pathway genes (yuc2, aao1, ami1) and by repression of the main gene (pin1) involved in IAA translocation [98] (Figure 4). Auxin build-up reduces primary root length and alters secondary root emergence [99]. Chitosan also affects regulation of gibberellic acid [100]. This polymer also alters patterns of expression of stress-related hormones jasmonic (JA) and salicylic acid (SA) genes in roots [98]. These transcriptomical and physiological changes can be elicited by other abiotic stresses [101,102]. Stress caused by application of high chitosan doses causes JA, SA and ROS accumulation in Arabidopsis roots together with other pleiotropic effects [98]. Cross-talk between abiotic and biotic stress responses in plants involves ROS and hormone signaling [103]. Therefore, chitosan irrigation treatments must avoid overstress to plant roots. Chitosan concentrations used in agricultural practices should restrict growth of pathogens, but favor growth of beneficial fungi (BCF) and plants.

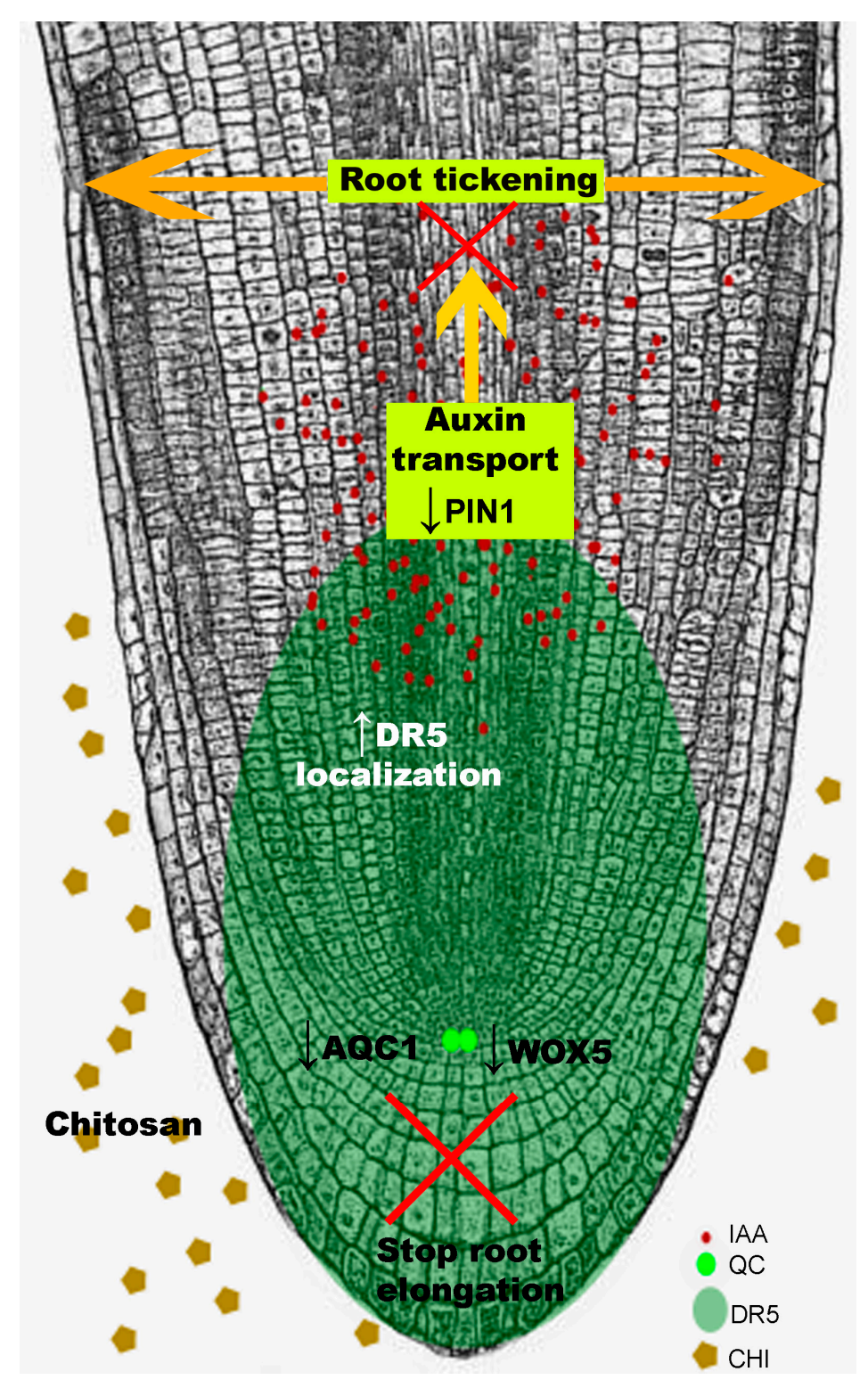

Figure 4. Chitosan causes auxin accumulation in roots. This is shown by lack of auxin transport in the vascular system (no DR5 expression). This auxin accumulation represses wox5, which controls activity of the quiescent center and in turn root polar growth. As a result, root stops elongating and root apex thickens. ROS and phenolic accumulation are associated with programmed cell death and stress-hormone (JA, SA) accumulation. 


\section{Plant Immunity: Role of Chitin/Chitosan}

Chitin is a key structural component of fungal cell walls. Plant chitinases and glucanases release chitin and $\beta$-glucan oligomers from cell walls of fungal pathogens. These oligomers (MAMPs, microbe-associated molecular patterns) are recognised by plant membrane PRRs (pattern recognition receptors) triggering a PTI (pattern-triggered immunity [104]) response. Some fungal pathogens can modify their cell walls during plant tissue colonisation, turning chitin into chitosan $[8,105]$. This may protect hyphae of fungal pathogens from plant chitinases. Very low concentrations (picomolar; pM) of chitin oligomers can still trigger PTI [106]. Chitin oligomers with large degrees of acetylation and polymerisation induce main PTI responses (ROS production and alkalinisation) [107-109]. Chitosan induces callose deposition in plants [110]. Plant immunity also involves overexpression of PR (Pathogenesis-Related) proteins in response to fungi and other pathogens. PR-4 family includes class-I and -II chitinases, responsible for chitin degradation [111,112]. Chitosan induces expression of PR proteins (NPR1) in roots [98] and leaves (PR1 and PR5) [113]. Plant chitinases show less affinity for chitosan than chitin. Therefore, chitosan is a less efficient MAMP than chitin $[8,108]$. Chitosan is also a component of the cell wall in germ tube and appressoria in the fungal pathogen Magnaporthe oryzae [114]. M. oryzae expresses CDAs during appressorium development. Deletion of these genes compromises conidia germination, adhesion and appressoria differentiation. Application of exogenous chitosan restores normal development [114]. M. oryzae chitosan on the surface of the leaf gives stimuli to promote adhesion, appressorium development and plant infection. Therefore, chitosan could promote evasion of plant immunity and fitness/virulence of fungal pathogens, including biocontrol agents like P. chlamydosporia. Plant pathogenic fungi also induce other structural changes in their cell walls to avoid plant defenses such as accumulation of $\alpha-1,3$-glucan. Masking chitin in fungal cell walls with $\alpha-1,3$-glucan also provides protection from plant chitinases. This delays PTI activation triggered by MAMP (chitin oligomers) recognition [8].

Fungal pathogens also avoid plant immunity shielding cell wall chitin with effectors. These mostly secreted proteins facilitate pathogen entry into the host and modulate plant immune perception (PTI) altering host physiology for pathogen's benefit [115]. LysM effectors bind chitin and chitin oligomers limiting PTI responses [116]. In this way, they protect fungal pathogens from plant chitinases [8]. They also prevent recognition of chitin oligomers (MAMPs) by plant PRR. Chitin elicitor binding proteins (CEBiP/CERK) are essential in chitin perception by plants. However, chitosan does not have specific receptors in plants [117]. This would be an additional reason why chitosan does not efficiently activate PTI responses. LysM effectors could protect fungal plant pathogens avoiding perception by mycoparasitic fungi [118]. Likewise, LysM domains can recognise peptidoglycan and could agglutinate bacterial competitors of plant pathogenic fungi. Just like pathogenic fungi, mutualistic endophytes (including mycorrhizae) also secrete LysM effectors to suppress plant immunity. These fungi can manipulate plant hormone signaling associated with plant defenses [115,119]. Chitin derivatives (Nod and Myc factors) act as symbiotic signaling compounds for rhizobia and mycorrhiza [120,121]. LysM proteins protect entomopathogenic fungi from insect immune system [122]. B. bassiana activates Blys2 and Blys5 (containing five and two LysM domains, respectively) expression during insect infection. Blys5 besides chitin can also bind chitosan and cellulose. Both LysM proteins are essential for full fungal virulence and could protect hyphae from host chitinases.

\section{Concluding Remarks}

Chitosan is a versatile compound with a wide range of applications. In the clinical field, chitosan can inhibit filamentous fungi (e.g., Aspergillus fumigatus) and yeast (e.g., Candida albicans) human pathogens. Application of chitosan under low nutrient $(\mathrm{C}$ and $\mathrm{N})$ status favors the antifungal mode of action of this polymer on human pathogenic fungi. Chitosan also reduces development of the model fungus N. crassa. Chitosan drastically reduces N. crassa spore germination and growth development. $N$. crassa spores exposed to chitosan induce expression of a lipase Class III, a monosaccharide transporter and a glutathione transferase encoding genes. These are the main chitosan targets in 
this filamentous fungus. A membrane protein ARL1 is the main chitosan target in the model yeast $S$. cerevisiae [63]. These proteins could be chitosan targets in fungi and their study could help to develop chitosan as a drug. On the other hand, chitosan is compatible with several BCF (P. chlamydosporia, B. bassiana or Trichoderma spp.). A high amount of saturated FFA in the plasma membrane together with a high glucan/chitin ratio in the cell wall make fungi resistant to chitosan (Figure 2). Chitosan is also compatible with biocontrol fungi applied in planta. However, application of chitosan on plant should be highly regulated. High doses of chitosan could block plant (tomato and barley) growth and development affecting root meristem architecture and organization. In Arabidopsis, the main transcription factor (WOX5) that regulates cell division in the root quiescent center is repressed by chitosan [98]. Besides, chitosan also alters hormone homeostasis. Chitosan stimulates auxin (IAA) accumulation in roots avoiding its translocation. Besides auxin, JA and SA accumulation in roots would explain changes of cell organisation in Arabidopsis roots exposed to chitosan. Chitosan and chitin also play a key role controlling plant immunity. Mainly chitin but also chitosan act as MAMPs triggering a PTI immune response in plants. Chitosan could play a crucial role for fungal endophytes and pathogens colonizing plants generating a fight between plant immunity and fungal virulence.

Author Contributions: F.L.-M. design, data interpretation and writing the manuscript. M.S.-F. writing the manuscript. L.V.L.-L. writing the manuscript and English editing.

Funding: This work was supported by European Project H2020 MUSA 727624.

Acknowledgments: Authors would like to thank Dr Aranda-Martinez for cell wall artwork and MSc Ana Lozano-Soria for editing help.

Conflicts of Interest: The authors declare no conflict of interest.

\section{References}

1. Kaur, S.; Dhillon, G.S. The versatile biopolymer chitosan: Potential sources, evaluation of extraction methods and applications. Crit. Rev. Microbiol. 2014, 40, 155-175. [CrossRef] [PubMed]

2. Ifuku, S. Chitin and chitosan nanofibers: Preparation and chemical modifications. Molecules 2014, 19, 18367-18380. [CrossRef] [PubMed]

3. Ravi Kumar, M.N. A review of chitin and chitosan applications. React. Funct. Polym. 2000, 46, 1-27. [CrossRef]

4. Younes, I.; Rinaudo, M. Chitin and chitosan preparation from marine sources. Structure, properties and applications. Mar. Drugs 2015, 13, 1133-1174. [CrossRef]

5. Hamer, S.N.; Cord-Landwehr, S.; Biarnés, X.; Planas, A.; Waegeman, H.; Moerschbacher, B.M.; Kolkenbrock, S. Enzymatic production of defined chitosan oligomers with a specific pattern of acetylation using a combination of chitin oligosaccharide deacetylases. Sci. Rep. 2015, 5, 8716. [CrossRef] [PubMed]

6. Aragunde, H.; Biarnés, X.; Planas, A.; Aragunde, H.; Biarnés, X.; Planas, A. Substrate recognition and specificity of chitin deacetylases and related family 4 carbohydrate esterases. Int. J. Mol. Sci. 2018, 19, 412. [CrossRef]

7. Pascual, S.; Planas, A. Screening assay for directed evolution of chitin deacetylases: Application to Vibrio cholerae deacetylase mutant libraries for engineered specificity. Anal. Chem. 2018, 90, 10654-10658. [CrossRef] [PubMed]

8. Sánchez-Vallet, A.; Mesters, J.R.; Thomma, B.P.H.J. The battle for chitin recognition in plant-microbe interactions. FEMS Microbiol. Rev. 2015, 39, 171-183. [CrossRef]

9. Pusztahelyi, T. Chitin and chitin-related compounds in plant-fungal interactions. Mycology 2018, 9, 189-201. [CrossRef]

10. Cord-Landwehr, S.; Melcher, R.L.J.; Kolkenbrock, S.; Moerschbacher, B.M. A chitin deacetylase from the endophytic fungus Pestalotiopsis sp. efficiently inactivates the elicitor activity of chitin oligomers in rice cells. Sci. Rep. 2016, 6, 38018. [CrossRef]

11. Aranda-Martinez, A.; Lenfant, N.; Escudero, N.; Zavala-Gonzalez, E.A.; Henrissat, B.; Lopez-Llorca, L.V. CAZyme content of Pochonia chlamydosporia reflects that chitin and chitosan modification are involved in nematode parasitism: CAZome of Pochonia chlamydosporia. Environ. Microbiol. 2016, 18, 4200-4215. [CrossRef] [PubMed] 
12. Aranda-Martinez, A.; Grifoll-Romero, L.; Aragunde, H.; Sancho-Vaello, E.; Biarnés, X.; Lopez-Llorca, L.V.; Planas, A. Expression and specificity of a chitin deacetylase from the nematophagous fungus Pochonia chlamydosporia potentially involved in pathogenicity. Sci. Rep. 2018, 8, 2170. [CrossRef] [PubMed]

13. Quiñones, J.P.; Peniche, H.; Peniche, C. Chitosan based self-assembled nanoparticles in drug delivery. Polymers 2018, 10, 235. [CrossRef]

14. Hamedi, H.; Moradi, S.; Hudson, S.M.; Tonelli, A.E. Chitosan based hydrogels and their applications for drug delivery in wound dressings: A review. Carbohydr. Polym. 2018, 199, 445-460. [CrossRef] [PubMed]

15. Acosta, N.; Sánchez, E.; Calderón, L.; Cordoba-Diaz, M.; Cordoba-Diaz, D.; Dom, S.; Heras, Á. Physical stability studies of semi-solid formulations from natural compounds loaded with chitosan microspheres. Mar. Drugs 2015, 13, 5901-5919. [CrossRef] [PubMed]

16. Zarayneh, S.; Sepahi, A.A.; Jonoobi, M.; Rasouli, H. Comparative antibacterial effects of cellulose nanofiber, chitosan nanofiber, chitosan/cellulose combination and chitosan alone against bacterial contamination of Iranian banknotes. Int. J. Biol. Macromol. 2018, 118, 1045-1054. [CrossRef] [PubMed]

17. Cremar, L.; Gutierrez, J.; Martinez, J.; Materon, L.; Gilkerson, R.; Xu, F.; Lozano, K. Development of antimicrobial chitosan based nanofiber dressings for wound healing applications. Nanomed. J. 2018, 5, 6-14.

18. Lopez-Moya, F.; Lopez-Llorca, L.V. Omics for investigating chitosan as an antifungal and gene modulator. J. Fungi 2016, 2, 11. [CrossRef]

19. Allan, C.R.; Hadwiger, L.A. The fungicidal effect of chitosan on fungi of varying cell wall composition. Exp. Mycol. 1979, 3, 285-287. [CrossRef]

20. Wang, Z.; Zheng, L.; Li, C.; Wu, S.; Xiao, Y. Preparation and antimicrobial activity of sulfopropyl chitosan in an ionic liquid aqueous solution. J. Appl. Polym. Sci. 2017, 134, 44989. [CrossRef]

21. Amato, A.; Migneco, L.M.; Martinelli, A.; Pietrelli, L.; Piozzi, A.; Francolini, I. Antimicrobial activity of catechol functionalized-chitosan versus Staphylococcus epidermidis. Carbohydr. Polym. 2018, 179, $273-281$. [CrossRef] [PubMed]

22. Park, Y.; Kim, M.H.; Park, S.C.; Cheong, H.; Jang, M.K.; Nah, J.W.; Hahm, K.S. Investigation of the antifungal activity and mechanism of action of LMWS-chitosan. J. Microbiol. Biotechnol. 2008, 18, 1729-1734. [PubMed]

23. Raafat, D.; von Bargen, K.; Haas, A.; Sahl, H.G. Insights into the mode of action of chitosan as an antibacterial compound. J. Appl. Environ. Microbiol. 2008, 74, 3764-3773. [CrossRef] [PubMed]

24. Kong, M.; Chen, X.G.; Xing, K.; Park, H.J. Antimicrobial properties of chitosan and mode of action: A state of the art review. Int. J. Food Microbiol. 2010, 144, 51-63. [CrossRef] [PubMed]

25. Ghaouth, A.; Arul, J.; Ponnampalam, R.; Boulet, M. Chitosan coating effect on storability and quality of fresh strawberries. Int. J. Food Sci. 1991, 56, 1618-1620. [CrossRef]

26. Verlee, A.; Mincke, S.; Stevens, C.V. Recent developments in antibacterial and antifungal chitosan and its derivatives. Carbohydr. Polym. 2017, 164, 268-283. [CrossRef]

27. Long, L.T.; Tan, L.V.; Boi, V.N.; Trung, T.S. Antifungal activity of water-soluble chitosan against Colletotrichum capsici in postharvest chili pepper. J. Food Process. Preserv. 2018, 42, e13339. [CrossRef]

28. Liu, Q.; Zhang, J.; Li, D.; Lang, J.; Zai, S.; Hao, J.; Wang, X. Inhibition of amphiphilic N-Alkyl-O-carboxymethyl chitosan derivatives on Alternaria macrospora. BioMed Res. Int. 2018, 5, 1-9. [CrossRef] [PubMed]

29. Palma-Guerrero, J.; Jansson, H.B.; Salinas, J.; Lopez-Llorca, L.V. Effect of chitosan on hyphal growth and spore germination of plant pathogenic and biocontrol fungi. J. Appl. Microbiol. 2008, 104, 541-553. [CrossRef]

30. Xing, Y.; Xu, Q.; Yang, S.X.; Chen, C.; Tang, Y.; Sun, S.; Zhang, L.; Che, Z.; Li, X. Preservation mechanism of chitosan-based coating with cinnamon oil for fruits storage based on sensor data. Sensors 2016, 16, 1111. [CrossRef] [PubMed]

31. Zavala-González, E.A.; Lopez-Moya, F.; Aranda-Martinez, A.; Cruz-Valerio, M.; Lopez-Llorca, L.V.; Ramírez-Lepe, M. Tolerance to chitosan by Trichoderma species is associated with low membrane fluidity. J. Basic Microbiol. 2016, 56, 792-800. [CrossRef] [PubMed]

32. Calamari, S.E.; Bojanich, M.A.; Barembaum, S.R.; Berdicevski, N.; Azcurra, A.I. Antifungal and post-antifungal effects of chlorhexidine, fluconazole, chitosan and its combinations on Candida albicans. Med. Oral Patol. Oral Cir. Bucal 2011, 16, e23-e28. [CrossRef]

33. Peña, A.; Sánchez, N.S.; Calahorra, M. Effects of Chitosan on Candida albicans: Conditions for its antifungal activity. BioMed Res. Int. 2013, 2013, 527549. [CrossRef] 
34. Kulikov, S.N.; Lisovskaya, S.A.; Zelenikhin, P.V.; Bezrodnykh, E.A.; Shakirova, D.R.; Blagodatskikh, I.V.; Tikhonov, V.E. Antifungal activity of oligochitosans (short chain chitosans) against some Candida species and clinical isolates of Candida albicans: Molecular weight-activity relationship. Eur. J. Med. Chem. 2014, 74, 169-178. [CrossRef] [PubMed]

35. Younes, I.; Sellimi, S.; Rinaudo, M.; Jellouli, K.; Nasri, M. Influence of acetylation degree and molecular weight of homogeneous chitosans on antibacterial and antifungal activities. Int. J. Food Microbiol. 2014, 185, 57-63. [CrossRef] [PubMed]

36. Lopez-Moya, F.; Kowbel, D.; Nueda, M.J.; Palma-Guerrero, J.; Glass, N.L.; Lopez-Llorca, L.V. Neurospora crassa transcriptomics reveals oxidative stress and plasma membrane homeostasis biology genes as key targets in response to chitosan. Mol. BioSyst. 2016, 12, 391-403. [CrossRef]

37. Palma-Guerrero, J.; Huang, I.C.; Jansson, H.B.; Salinas, J.; Lopez-Llorca, L.V.; Read, N.D. Chitosan permeabilizes the plasma membrane and kills cells of Neurospora crassa in an energy dependent manner. Fungal Genet. Biol. 2009, 46, 585-594. [CrossRef]

38. Je, J.Y.; Kim, S.K. Chitosan derivatives killed bacteria by disrupting the outer and inner membrane. J. Agric. Food Chem. 2006, 54, 6629-6633. [CrossRef]

39. Tang, H.; Zhang, P.; Kieft, T.L.; Ryan, S.J.; Baker, S.M.; Wiesmann, W.P.; Rogelj, S. Antibacterial action of a novel functionalized chitosan-arginine against Gram-negative bacteria. Acta Biomater. 2010, 6, 2562-2571. [CrossRef]

40. Mu, H.; Guo, F.; Niu, H.; Liu, Q.; Wang, S.; Duan, J. Chitosan improves anti-biofilm efficacy of gentamicin through facilitating antibiotic penetration. Int. J. Mol. Sci. 2014, 15, 22296-22308. [CrossRef]

41. Erman, A.; Hergouth, V.K.; Blango, M.G.; Kos, M.K.; Mulvey, M.A.; Veranič, P. Repeated treatments with chitosan in combination with antibiotics completely eradicate uropathogenic Escherichia coli from infected mouse urinary bladders. J. Infect. Dis. 2017, 216, 375-381. [CrossRef]

42. Alburquenque, C.; Bucarey, S.A.; Neira-Carrillo, A.; Urzúa, B.; Hermosilla, G.; Tapia, C.V. Antifungal activity of low molecular weight chitosan against clinical isolates of Candida spp. Med. Mycol. 2010, 48, 1018-1023. [CrossRef]

43. Lopez-Moya, F.; Colom-Valiente, M.F.; Martinez-Peinado, P.; Martinez-Lopez, J.E.; Puelles, E.; Sempere-Ortells, J.M.; Lopez-Llorca, L.V. Carbon and nitrogen limitation increase chitosan antifungal activity in Neurospora crassa and fungal human pathogens. Fungal Biol. 2015, 119, 154-169. [CrossRef]

44. Kvasničková, E.; Paulíček, V.; Paldrychová, M.; Ježdík, R.; Mat'átková, O.; Masák, J. Aspergillus fumigatus DBM 4057 biofilm formation is inhibited by chitosan, in contrast to baicalein and rhamnolipid. World J. Microbiol. Biotechnol. 2016, 32, 187. [CrossRef]

45. Nitsche, B.M.; Jørgensen, T.R.; Akeroyd, M.; Meyer, V.; Ram, A.F. The carbon starvation response of Aspergillus niger during submerged cultivation: Insights from the transcriptome and secretome. BMC Genomics 2012, 13, 380. [CrossRef]

46. Szilágyi, M.; Miskei, M.; Karányi, Z.; Lenkey, B.; Pócsi, I.; Emri, T. Transcriptome changes initiated by carbon starvation in Aspergillus nidulans. Microbiology 2013, 159, 176-190. [CrossRef]

47. Valiante, V.; Macheleidt, J.; Föge, M.; Brakhage, A.A. The Aspergillus fumigatus cell wall integrity-signaling pathway: Drug target, compensatory pathways, and virulence. Front. Microbiol. 2015, 6, 325. [CrossRef]

48. Levdansky, E.; Kashi, O.; Sharon, H.; Shadkchan, Y.; Osherov, N. The Aspergillus fumigatus cspA gene encoding a repeat-rich cell wall protein is important for normal conidial cell wall architecture and interaction with host cells. Eukaryot. Cell 2010, 9, 1403-1415. [CrossRef]

49. Maddi, A.; Free, S.J. $\alpha-1,6-$ Mannosylation of N-Linked oligosaccharide present on cell wall proteins is required for their incorporation into the cell wall in the filamentous fungus Neurospora crassa. Eukaryot. Cell 2010, 9, 1766-1775. [CrossRef]

50. Pu, Y.; Liu, A.; Zheng, Y.; Ye, B. In vitro damage of Candida albicans biofilms by chitosan. Exp. Ther. Med. 2014, 8, 929-934. [CrossRef]

51. Camacho, E.; Chrissian, C.; Cordero, R.J.B.; Liporagi-Lopes, L.; Stark, R.E.; Casadevall, A. $\mathrm{N}$-acetylglucosamine affects Cryptococcus neoformans cell-wall composition and melanin architecture. Microbiology 2017, 163, 1540-1556. [CrossRef]

52. Garcia, L.G.S.; Guedes, G.M.; da Silva, M.L.Q.; Castelo-Branco, D.S.C.M.; Sidrim, J.J.C.; de Cordeiro, R.A.; Rocha, M.F.G.; Vieira, R.S.; Brilhante, R.S.N. Effect of the molecular weight of chitosan on its antifungal activity against Candida spp. in planktonic cells and biofilm. Carbohydr. Polym. 2018, 195, 662-669. [CrossRef] 
53. Fuchs, B.B.; O’Brien, E.; Khoury, J.B.E.; Mylonakis, E. Methods for using Galleria mellonella as a model host to study fungal pathogenesis. Virulence 2010, 1, 475-482. [CrossRef]

54. Ramarao, N.; Nielsen-Leroux, C.; Lereclus, D. The insect Galleria mellonella as a powerful infection model to investigate bacterial pathogenesis. J. Vis. Exp. 2012, 70, e4392. [CrossRef]

55. Li, D.D.; Deng, L.; Hu, G.H.; Zhao, L.X.; Hu, D.D.; Jiang, Y.Y.; Wang, Y. Using Galleria mellonella-Candida albicans infection model to evaluate antifungal agents. Biol. Pharm. Bull. 2013, 36, 1482-1487. [CrossRef]

56. Bégin, A.; Van Calsteren, M.R. Antimicrobial films produced from chitosan. Int. J. Biol. Macromol. 1999, 26, 63-67. [CrossRef]

57. El Hadrami, A.; Adam, L.R.; El Hadrami, I.; Daayf, F. Chitosan in Plant Protection. Mar. Drugs 2010, 8, 968-987. [CrossRef]

58. Ing, L.Y.; Zin, N.M.; Sarwar, A.; Katas, H. Antifungal activity of chitosan nanoparticles and correlation with their physical properties. Int. J. Biomater. 2012, 2012, 1-9. [CrossRef]

59. Jayash, S.N.; Hashim, N.M.; Misran, M.; Baharuddin, N.A. Formulation and in vitro and in vivo evaluation of a new osteoprotegerin-chitosan gel for bone tissue regeneration. J. Biomed. Mater. Res. A 2017, 105, 398-407. [CrossRef]

60. Debnath, S.K.; Saisivam, S.; Debanth, M.; Omri, A. Development and evaluation of Chitosan nanoparticles based dry powder inhalation formulations of Prothionamide. PLoS ONE 2018, 13, e0190976. [CrossRef]

61. De Matteis, L.; Jary, D.; Lucía, A.; García-Embid, S.; Serrano-Sevilla, I.; Pérez, D.; Ainsa, J.A.; Navarro, F.P.; de la Fuente, J.M. New active formulations against M. tuberculosis: Bedaquiline encapsulation in lipid nanoparticles and chitosan nanocapsules. Chem. Eng. J. 2018, 340, 181-191. [CrossRef]

62. Palma-Guerrero, J.; Lopez-Jimenez, J.A.; Pérez-Berná, A.J.; Huang, I.C.; Jansson, H.B.; Salinas, J.; Villalaín, J.; Read, N.D.; Lopez-Llorca, L.V. Membrane fluidity determines sensitivity of filamentous fungi to chitosan. Mol. Microbiol. 2010, 75, 1021-1032. [CrossRef]

63. Jaime, M.D.L.A.; Lopez-Llorca, L.V.; Conesa, A.; Lee, A.Y.; Proctor, M.; Heisler, L.E.; Gebbia, M.; Giaever, G.; Westwood, J.T.; Nislow, C. Identification of yeast genes that confer resistance to chitosan oligosaccharide (COS) using chemogenomics. BMC Genomics 2012, 13, 267. [CrossRef]

64. Zakrzewska, A.; Boorsma, A.; Brul, S.; Hellingwerf, K.J.; Klis, F.M. Transcriptional response of Saccharomyces cerevisiae to the plasma membrane-perturbing compound chitosan. Eukaryot. Cell 2005, 4, 703-715. [CrossRef]

65. Kaiserer, L.; Oberparleiter, C.; Weiler-Gorz, R.; Burgstaller, W.; Leiter, E.; Marx, F. Characterization of the Penicillium chrysogenum antifungal protein PAF. Arch. Microbiol. 2003, 180, 204-210. [CrossRef]

66. Marx, F.; Binder, U.; Leiter, É.; Pócsi, I. The Penicillium chrysogenum antifungal protein PAF, a promising tool for the development of new antifungal therapies and fungal cell biology studies. Cell. Mol. Life Sci. 2008, 65, 445-454. [CrossRef]

67. Ng, T.S.; Desa, M.N.M.; Sandai, D.; Chong, P.P.; Than, L.T.L. Growth, biofilm formation, antifungal susceptibility and oxidative stress resistance of Candida glabrata are affected by different glucose concentrations. Infect. Genet. Evol. 2016, 40, 331-338. [CrossRef]

68. Mota, S.; Alves, R.; Carneiro, C.; Silva, S.; Brown, A.J.; Istel, F.; Kuchler, K.; Sampaio, P.; Casal, M.; Henriques, M.; et al. Candida glabrata susceptibility to antifungals and phagocytosis is modulated by acetate. Front. Microbiol. 2015, 6, 919. [CrossRef]

69. Brodhun, F.; Feussner, I. Oxylipins in fungi. FEBS J. 2011, 278, 1047-1063. [CrossRef]

70. Fu, C.; Ao, J.; Dettmann, A.; Seiler, S.; Free, S.J. Characterization of the Neurospora crassa Cell Fusion Proteins, HAM-6, HAM-7, HAM-8, HAM-9, HAM-10, AMPH-1 and WHI-2. PLoS ONE 2014, 9, e107773. [CrossRef]

71. Muñoz, A.; Chu, M.; Marris, P.I.; Sagaram, U.S.; Kaur, J.; Shah, D.M.; Read, N.D. Specific domains of plant defensins differentially disrupt colony initiation, cell fusion and calcium homeostasis in Neurospora crassa. Mol. Microbiol. 2014, 92, 1357-1374. [CrossRef]

72. Groppi, S.; Belotti, F.; Brandão, R.L.; Martegani, E.; Tisi, R. Glucose-induced calcium influx in budding yeast involves a novel calcium transport system and can activate calcineurin. Cell Calcium 2011, 49, 376-386. [CrossRef]

73. Cavinder, B.; Trail, F. Role of Fig1, a Component of the low-affinity calcium uptake system, in growth and sexual development of filamentous fungi. Eukaryot. Cell 2012, 11, 978-988. [CrossRef]

74. Palma-Guerrero, J.; Leeder, A.C.; Welch, J.; Glass, N.L. Identification and characterization of LFD1, a novel protein involved in membrane merger during cell fusion in Neurospora crassa. Mol. Microbiol. 2014, 92, 164-182. [CrossRef] 
75. Yan, Y.; Wei, C.; Zhang, W.; Cheng, H.; Liu, J. Cross-talk between calcium and reactive oxygen species signaling. Acta Pharmacol. Sin. 2006, 27, 821-826. [CrossRef]

76. Tian, H.; Qu, S.; Wang, Y.; Lu, Z.; Zhang, M.; Gan, Y.; Zhang, P.; Tian, J. Calcium and oxidative stress mediate perillaldehyde-induced apoptosis in Candida albicans. Appl. Microbiol. Biotechnol. 2017, 101, 3335-3345. [CrossRef]

77. Awasthi, B.P.; Mitra, K. In vitro leishmanicidal effects of the anti-fungal drug natamycin are mediated through disruption of calcium homeostasis and mitochondrial dysfunction. Apoptosis 2018, 23, 420-435. [CrossRef]

78. Laflamme, P.; Benhamou, N.; Bussières, G.; Dessureault, M. Differential effect of chitosan on root rot fungal pathogens in forest nurseries. Can. J. Bot. 2000, 77, 1460-1468. [CrossRef]

79. Escudero, N.; Ferreira, S.R.; Lopez-Moya, F.; Naranjo-Ortiz, M.A.; Marin-Ortiz, A.I.; Thornton, C.R.; Lopez-Llorca, L.V. Chitosan enhances parasitism of Meloidogyne javanica eggs by the nematophagous fungus Pochonia chlamydosporia. Fungal Biol. 2016, 120, 572-585. [CrossRef]

80. Aranda-Martinez, A.; Naranjo Ortiz, M.Á.; Abihssira García, I.S.; Zavala-Gonzalez, E.A.; Lopez-Llorca, L.V. Ethanol production from chitosan by the nematophagous fungus Pochonia chlamydosporia and the entomopathogenic fungi Metarhizium anisopliae and Beauveria bassiana. Microbiol. Res. 2017, 204, 30-39. [CrossRef]

81. Larriba, E.; Jaime, M.D.L.A.; Carbonell-Caballero, J.; Conesa, A.; Dopazo, J.; Nislow, C.; Martín-Nieto, J.; Lopez-Llorca, L.V. Sequencing and functional analysis of the genome of a nematode egg-parasitic fungus, Pochonia chlamydosporia. Fungal Genet. Biol. 2014, 65, 69-80. [CrossRef]

82. Palma-Guerrero, J.; Gómez-Vidal, S.; Tikhonov, V.E.; Salinas, J.; Jansson, H.B.; Lopez-Llorca, L.V. Comparative analysis of extracellular proteins from Pochonia chlamydosporia grown with chitosan or chitin as main carbon and nitrogen sources. Enzyme Microb. Technol. 2010, 46, 568-574. [CrossRef]

83. Aktar, W.; Sengupta, D.; Chowdhury, A. Impact of pesticides use in agriculture: Their benefits and hazards. Interdiscip. Toxicol. 2009, 2, 1-12. [CrossRef]

84. Goucher, L.; Bruce, R.; Cameron, D.D.; Koh, S.C.L.; Horton, P. The environmental impact of fertilizer embodied in a wheat-to-bread supply chain. Nat. Plants 2017, 3, 17012. [CrossRef]

85. Clark, M.; Tilman, D. Comparative analysis of environmental impacts of agricultural production systems, agricultural input efficiency, and food choice. Environ. Res. Lett. 2017, 12, 064016. [CrossRef]

86. Xing, K.; Zhu, X.; Peng, X.; Qin, S. Chitosan antimicrobial and eliciting properties for pest control in agriculture: A review. Agron. Sustain. Dev. 2015, 35, 569-588. [CrossRef]

87. Xing, K.; Li, T.J.; Liu, Y.F.; Zhang, J.; Zhang, Y.; Shen, X.Q.; Li, X.Y.; Miao, X.M.; Feng, Z.Z.; Peng, X.; et al. Antifungal and eliciting properties of chitosan against Ceratocystis fimbriata in sweet potato. Food Chem. 2018, 268, 188-195. [CrossRef]

88. Ghormade, V.; Deshpande, M.V.; Paknikar, K.M. Perspectives for nano-biotechnology enabled protection and nutrition of plants. Biotechnol. Adv. 2011, 29, 792-803. [CrossRef]

89. Lafontaine, P.J.; Benhamou, N. Chitosan treatment: An emerging strategy for enhancing resistance of greenhouse tomato plants to infection by Fusarium oxysporum f.sp. radicis-lycopersici. Biocontrol. Sci. Technol. 1996, 6, 111-124. [CrossRef]

90. Muzzarelli, R.A.A.; Muzzarelli, C.; Tarsi, R.; Miliani, M.; Gabbanelli, F.; Cartolari, M. Fungistatic activity of modified chitosans against Saprolegnia parasitica. Biomacromolecules 2001, 2, 165-169. [CrossRef]

91. Rabea, E.I.; Badawy, M.E.T.; Stevens, C.V.; Smagghe, G.; Steurbaut, W. Chitosan as antimicrobial agent: Applications and mode of action. Biomacromolecules 2003, 4, 1457-1465. [CrossRef]

92. Mwaheb, M.A.; Hussain, M.; Tian, J.; Zhang, X.; Hamid, M.I.; El-Kassim, N.A.; Hassan, G.M.; Xiang, M.; Liu, X. Synergetic suppression of soybean cyst nematodes by chitosan and Hirsutella minnesotensis via the assembly of the soybean rhizosphere microbial communities. Biol. Control 2017, 115, 85-94. [CrossRef]

93. Escudero, N.; Lopez-Moya, F.; Ghahremani, Z.; Zavala-Gonzalez, E.A.; Alaguero-Cordovilla, A.; Ros-Ibañez, C.; Lacasa, A.; Sorribas, F.J.; Lopez-Llorca, L.V. Chitosan increases tomato root colonization by Pochonia chlamydosporia and their combination reduces root-knot nematode damage. Front. Plant Sci. 2017, 8 , 1415. [CrossRef]

94. Kananont, N.; Pichyangkura, R.; Chanprame, S.; Chadchawan, S.; Limpanavech, P. Chitosan specificity for the in vitro seed germination of two Dendrobium orchids (Asparagales: Orchidaceae). Sci. Hortic. 2010, 124, 239-247. [CrossRef] 
95. Ohta, K.; Taniguchi, A.; Konishi, N.; Hosoki, T. Chitosan treatment affects plant growth and flower quality in Eustoma grandiflorum. HortScience 1999, 34, 233-234.

96. El-Tantawy, E.M. Behaviour of tomato plants as affected by spraying with chitosan and aminofort as natural stimulator substances under application of soil organic amendments. Pak. J. Biol. Sci. 2009, 12, 1164-1173. [CrossRef]

97. Iriti, M.; Faoro, F. Abscisic acid is involved in chitosan-induced resistance to tobacco necrosis virus (TNV). J. Plant Biochem. Physiol. 2008, 46, 1106-1111. [CrossRef]

98. Lopez-Moya, F.; Escudero, N.; Zavala-Gonzalez, E.A.; Esteve-Bruna, D.; Blázquez, M.A.; Alabadí, D.; Lopez-Llorca, L.V. Induction of auxin biosynthesis and WOX5 repression mediate changes in root development in Arabidopsis exposed to chitosan. Sci. Rep. 2017, 7, 16813. [CrossRef]

99. Overvoorde, P.; Fukaki, H.; Beeckman, T. Auxin control of root development. Cold Spring Harb. Perspect. Biol. 2010, 2, a001537. [CrossRef]

100. Pereira, A.E.S.; Sandoval-Herrera, I.E.; Zavala-Betancourt, S.A.; Oliveira, H.C.; Ledezma-Pérez, A.S.; Romero, J.; Fraceto, L.F. $\gamma$-Polyglutamic acid/chitosan nanoparticles for the plant growth regulator gibberellic acid: Characterization and evaluation of biological activity. Carbohydr. Polym. 2017, 157, 1862-1873. [CrossRef]

101. Wasternack, C. Jasmonates: An update on biosynthesis, signal transduction and action in plant stress response, growth and development. Ann. Bot. 2007, 100, 681-697. [CrossRef]

102. Wasternack, C.; Hause, B. Jasmonates: Biosynthesis, perception, signal transduction and action in plant stress response, growth and development. An update to the 2007 review in Annals of Botany. Ann. Bot. 2013, 111, 1021-1058. [CrossRef]

103. Fujita, M.; Fujita, Y.; Noutoshi, Y.; Takahashi, F.; Narusaka, Y.; Yamaguchi-Shinozaki, K.; Shinozaki, K. Crosstalk between abiotic and biotic stress responses: A current view from the points of convergence in the stress signaling networks. Curr. Opin. Plant Biol. 2006, 9, 436-442. [CrossRef]

104. Jones, J.D.G.; Dangl, J.L. The plant immune system. Nature 2006, 444, 323-329. [CrossRef]

105. Geoghegan, I.; Steinberg, G.; Gurr, S. The role of the fungal cell wall in the infection of plants. Trends Microbiol. 2017, 25, 957-967. [CrossRef]

106. Felix, G.; Regenass, M.; Boller, T. Specific perception of subnanomolar concentrations of chitin fragments by tomato cells: Induction of extracellular alkalinization, changes in protein phosphorylation, and establishment of a refractory state. Plant J. 1993, 4, 307-316. [CrossRef]

107. Baureithel, K.; Felix, G.; Boller, T. Specific, high affinity binding of chitin fragments to tomato cells and membranes. Competitive inhibition of binding by derivatives of chitooligosaccharides and a Nod factor of Rhizobium. J. Biol. Chem. 1994, 269, 17931-17938.

108. Vander, P.; Vårum, K.M.; Domard, A.; Eddine El Gueddari, N.; Moerschbacher, B.M. Comparison of the ability of partially $N$-Acetylated chitosans and chitooligosaccharides to elicit resistance reactions in wheat leaves. Plant Physiol. 1998, 118, 1353-1359. [CrossRef]

109. Li, P.; Linhardt, R.; Cao, Z. Structural characterization of oligochitosan elicitor from Fusarium sambucinum and its elicitation of defensive responses in Zanthoxylum bungeanum. Int. J. Mol. Sci. 2016, 17, 2076. [CrossRef]

110. Luna, E.; Pastor, V.; Robert, J.; Flors, V.; Mauch-Mani, B.; Ton, J. Callose deposition: A multifaceted plant defense response. Mol. Plant Microbe Interact. 2011, 24, 183-193. [CrossRef]

111. van Loon, L.C.; Rep, M.; Pieterse, C.M.J. Significance of inducible defense-related proteins in infected plants. Annu. Rev. Phytopathol. 2006, 44, 135-162. [CrossRef]

112. Bravo, J.M.; Campo, S.; Murillo, I.; Coca, M.; San Segundo, B. Fungus and wound-induced accumulation of mRNA containing a class II chitinase of the pathogenesis-related protein 4 (PR-4) family of maize. Plant Mol. Biol. 2003, 52, 745-759. [CrossRef]

113. Beatrice, C.; Linthorst, J.M.H.; Cinzia, F.; Luca, R. Enhancement of PR1 and PR5 gene expressions by chitosan treatment in kiwifruit plants inoculated with Pseudomonas syringae pv. actinidiae. Eur. J. Plant Pathol. 2017, 148, 163-179. [CrossRef]

114. Geoghegan, I.A.; Gurr, S.J. Chitosan mediates germling Adhesion in Magnaporthe oryzae and is required for surface sensing and germling morphogenesis. PLoS Pathog. 2016, 12, e1005703. [CrossRef]

115. Rovenich, H.; Boshoven, J.C.; Thomma, B.P. Filamentous pathogen effector functions: Of pathogens, hosts and microbiomes. Curr. Opin. Plant Biol. 2014, 20, 96-103. [CrossRef] 
116. Desaki, Y.; Miyata, K.; Suzuki, M.; Shibuya, N.; Kaku, H. Plant immunity and symbiosis signaling mediated by LysM receptors. Innate Immunity 2018, 24, 92-100. [CrossRef]

117. Yin, H.; Du, Y.; Dong, Z. Chitin Oligosaccharide and Chitosan Oligosaccharide: Two Similar but Different Plant Elicitors. Front. Plant Sci. 2016, 7, 522. [CrossRef]

118. Kombrink, A.; Thomma, B.P.H.J. LysM Effectors: Secreted Proteins Supporting Fungal Life. PLoS Pathog. 2013, 9, e1003769. [CrossRef]

119. Vandenkoornhuyse, P.; Quaiser, A.; Duhamel, M.; Le Van, A.; Dufresne, A. The importance of the microbiome of the plant holobiont. New Phytol. 2015, 206, 1196-1206. [CrossRef]

120. Genre, A.; Russo, G. Does a common pathway transduce symbiotic signals in plant-microbe interactions? Front. Plant Sci. 2016, 7, 96. [CrossRef]

121. Mulder, L.; Lefebvre, B.; Cullimore, J.; Imberty, A. LysM domains of Medicago truncatula NFP protein involved in Nod factor perception. Glycosylation state, molecular modeling and docking of chitooligosaccharides and Nod factors. Glycobiology 2006, 16, 801-809. [CrossRef]

122. Cen, K.; Li, B.; Lu, Y.; Zhang, S.; Wang, C. Divergent LysM effectors contribute to the virulence of Beauveria bassiana by evasion of insect immune defenses. PLoS Pathog. 2017, 13, e1006604. [CrossRef]

(C) 2019 by the authors. Licensee MDPI, Basel, Switzerland. This article is an open access article distributed under the terms and conditions of the Creative Commons Attribution (CC BY) license (http://creativecommons.org/licenses/by/4.0/). 